\section{References}

1 Drake TS, Grunert GM. The unsuspected pelvic factor in the infertility investigation. Fertil Sueril $1980 ; 34 \cdot 27-32$

2 Strathy JH, Molgaard CA, Coulam CB, Melton LJ. Endometriosis and infertility: a laparoscopic study of endometriosis among fertile and infertile women. Fertil Steril 1982;38:667-72.

3 Peterson EP, Behrman SJ. Laparoscopy of the infertile patient. Obstet Gynecol 1970;36:363-7.

4 Goldenberg RL, Magendantz HG. Laparoscopy and the infertility evaluation. Obsta Gymecol 1976;47:410-4.

5 Hasson HM. Incidence of endometriosis in diagnostic laparoscopy. J Reprod Med 1976;16:135-8.

Schenken RS, Malinak LR. Conservative surgery versus expectant management for the infertile patient with mild endometriosis. Fertil Steril 1982;37:183-6.

7 Dmowski WP, Cohen MR. Antigonadotrophin (danazol) in the treatment of endometriosis. Evaluation of post treatment fertility and three year follow up data. Am $\mathcal{f}$ Obstet Gymecol 1978;130:41-7.

8 Buttram VC, Reiter RC, Ward S. Treatment of endometriosis with danazol: report of a 6 year prospective study. Fertil Steril 1985;43:353-60.

9 Seibel MM, Berger MJ, Weinstein FG, Taymor ML. The effectiveness of danazol on subsequent fertility in minimal endometriosis. Fertil Steril 1982;38:534-7.

10 Bayer $S$, Seibel $M$, Seffan $D$, Berger $M$, Taymor $M$. The efficacy of danazol treatment in an infertile population with mild endometriosis. Fertil Steril 1986;46(program suppl): 17.

11 Thomas EJ, Cooke ID. Impact of gestrinone on the course of asymptomatic endometriosis. BrMed f 1987;294:272-4.

12 American Fertility Society. Revised American Fertility Society classification of endometriosis. Fertil Steril 1985;43:351-2.

13 Lenton EA, Landgren B-M, Sexton L. Normal variation in the length of the luteal phase of the menstrual cycle: identification of the short luteal phase. Br $\mathcal{Y}$ Obstet Gynaecol 1984;91:685-9.

14 Lenton EA, Sulaiman R, Sobowale O, Cooke ID. The human menstrual cycle: plasma concentrations of prolactin, LH, FSH, oestradiol and progesterone in conceiving and nonconceiving women. I Reprod F ertil 1982;65:131-9.

15 Belsey MA, Eliasson R, Gallegos AJ, Moghissi K, Paulsen C, Prasad M. Laboratory manual for the examination of human semen and semen-cervical mucus interaction. Singapore: Press Concern, 1980.

16 Cooke ID, Sulaiman RA, Lenton EA, Parsons RJ. Fertility and infertility statistics: their importance and application. Clin Obstet Gymecol 1981;8:531-48.
17 Tietze C. Fertility after discontinuation of intrauterine and oral contraception. Int $\mathcal{J}$ Fertil 1968;13:385-9.

18 Lenton EA, Weston GA, Cooke ID. Long term follow-up of the apparently normal couple with a complaint of infertility. Fertil Steril 1977;28:913-9.

19 Pocock SJ. Statistical methods for determining trial size in clinical trials. Clinical trials: a practical approach. Chichester: John Wiley \& Sons, 1983:123-33.

20 Sondheimer SJ, Flickinger G. Prostaglandin $F_{2}$ in the peritoneal fluid of patients with endometriosis. Int f F erril 1982;27:73-5.

21 Badawy SZA, Cuenca V, Marshall L, Munchback R, Rinas AC, Coble DA. Cellular components in peritoneal fluid in infertile patients with and without endometriosis. Fertil Steril 1984;42: 7048 .

22 Muscato JJ, Haney AF, Weinberg JB. Sperm phagocytosis by human peritoneal macrophages: a possible cause for infertility in endometriosis. Am f Obstet Gymecol 1982;144:503-10.

23 Halme J, Becker S, Hammond MG, Ray MHG, Ray S. Increased activation of pelvic macrophages in infertile women with mild endometriosis. Am J Obstet Gynecol 1983;145:333-7.

24 Mathur S, Peress MR, Wiliamson HO, a al. Autoimmunity to endometrium and ovary in endometriosis. Clin Exp Imemunol 1982;50:259-66.

25 Steele RW, Dmowski WP, Marmer DJ. Immunologic aspects of human endometriosis. Am $\mathcal{J}$ Reprod Imemunol 1984;6:33-6.

26 Wardle PG, McLaughlin EA, McDermott A, Mitchell JD, Ray BD, Hull MGR. Endometriosis and ovulatory disorder: reduced fertilization in vitro compared with tubal and unexplained infertility. Lancer 1985;ii:236-9.

27 Soules MR, Malinak LR, Bury R, Poindexter A. Endometriosis and anovulation: a coexisting problem in the infertile female. Am $\mathcal{J}$ Obstet Gymecol 1976;125:412-5.

28 Diobsti WP, Cohen MR, Wilhelm JL Endometiosis and ovulatory failure: does it occur? Should ovulatory stimulating agents be used? In: Greenblatt RB, ed. Recent advances in
endometriosis. Amsterdam: Excerpta Medica, 1976:129-36. (Intemational Congress Series No 368.)

29 Koninckx PR, Brosens IA. The luteinised unruptured follicle syndrome. Obstet Gynecol Annu 1982;11:175-86.

30 Hull MGR, Savage PE, Bromham DR. Anovulatory and ovulatory infertility: results with simplified management. BrMed F 1982;284:1681-5.

31 Hull MGR, Glazener CMA, Kelly NJ, es al. Population study of courses, treatment, and outcome of infertility. Br Med J 1985;291:1693-7.

(Accepted 9 March 1987)

\title{
Effects of intradermal bradykinin after inhibition of angiotensin converting enzyme
}

\author{
R E FERNER, JUDY M SIMPSON, M D RAWLINS
}

\begin{abstract}
Inhibitors of angiotensin converting enzyme may cause angiooedema. To see if this might be due to potentiation of the tissue effects of bradykinin the thickness of weals raised by intradermal injection of saline or 1,3 , or $10 \mu \mathrm{g}$ bradykinin was measured before and three times after single doses of captopril, enalapril, or placebo. The mean thickness increased with increasing doses of bradykinin. It did not change with time after the administration of placebo or captopril but increased from $0.61 \mathrm{~mm}$ before enalapril to $1.12 \mathrm{~mm}$ two and a half hours and $1.06 \mathrm{~mm}$ five hours after enalapril was given. Five subjects flushed when given bradykinin after captopril and four after enalapril, but none flushed when given bradykinin after placebo.

It is concluded that angiotensin converting enzyme inhibitors potentiate the effects of intradermal bradykinin in vivo and that this may partially explain why they cause angio-oedema in susceptible patients.
\end{abstract}

\footnotetext{
Wolfson Unit of Clinical Pharmacology and Department of Medical Statistics,

University of Newcastle upon Tyne, Newcastle upon Tyne NE1 7RU

R E FERNER, MSC, MRCP, senior registrar

JUDY M SIMPSON, PHD, lecturer

M D RAWLINS, MD, FRCP, professor of clinical pharmacology

Correspondence to: Dr Ferner.
}

\section{Introduction}

Angio-oedema is an occasional but potentially fatal adverse reaction to angiotensin converting enzyme inhibitors. It occurs with both captopril and enalapril,,$^{2}$ and often develops within 48 hours after treatment is started. ${ }^{3}$ Bradykinin, a nonapeptide that causes vasodilatation and increased vascular permeability, has been implicated in the pathogenesis of the angio-oedema ${ }^{4}$ as it is inactivated by two distinct proteases, one of which (kininase II) is identical with angiotensin converting enzyme. ${ }^{5}$ Treatment with captopril increases the effect of intra-arterial bradykinin on forearm blood flow. ${ }^{6}$ Blood concentrations of bradykinin do not seem to be increased during treatment with angiotensin converting enzyme inhibitors. ${ }^{7}$ Thus the development of angio-oedema in patients receiving angiotensin converting enzyme inhibitors may be due to the reduced destruction of bradykinin formed locally in subcutaneous tissues. To investigate this possiblity we studied the effects of angiotensin converting enzyme inhibitors on dermal weals induced by bradykinin.

\section{Subjects and methods}

We studied six healthy subjects aged 22-45 with normal full blood count, urea and electrolyte concentrations, and results of biochemical tests of liver function. None had any history of cardiovascular disease, hypertension, or drug allergy or was taking any medicine. All gave written informed consent to the study, which was approved by the university ethics committee. The subjects fasted from midnight before each study, and each received on separate occasions oral captopril $25 \mathrm{mg}$, enalapril $10 \mathrm{mg}$, or lactose placebo in identical capsules according to a randomised double blind trial design.

Solutions of bradykinin (Sigma Chemical Co Ltd, Poole, Dorset) in 0.9\% 
saline were prepared on each experimental day to give concentrations of 10 , 30 , and $100 \mathrm{mg} /$. Solutions were sterilised with a $0.22 \mu \mathrm{m}$ filter (Millipore Corporation, Bedford, Massachusetts) and stored on ice until used. Two groups of four injection sites were marked on the volar aspect of each arm and $100 \mu \mathrm{l}$ injections of saline containing $0,1,3$, or $10 \mu \mathrm{g}$ bradykinin administered intradermally at one group of marked sites chosen at random. Skin thickness was measured in duplicate with modified Harpenden callipers $^{8}$ before and 20 minutes after the injection of bradykinin as preliminary experiments showed that the thickness of the weal was maximum at this time. Averages of all duplicate measurements were calculated. The response to each dose of bradykinin was calculated as the average increase in thickness of the bradykinin weal minus the average increase in thickness of the weal after administration of saline at the same time. Supine and standing blood pressures and pulse rate were measured by sphygmomanometry (Hawksley random zero sphygmomanometer) and palpation of the radial artery, respectively. Dose-response curves to intradermal bradykinin, blood pressure, and pulse rate were assessed just before and at two and a half, five, and seven and a half hours after administration of the drugs.

The mean responses to each dose of bradykinin and at each time were compared by within subject analyses of variance separately for each of the three treatments. Reanalysis using square root transformation produced homoscedasticity but made no difference to the conclusions so untransformed data are presented here. Two tailed tests were used, and differences were taken to be significant at $p<0.05$. The GLIM computer system was used for the analyses of variance and to obtain the standard error of the differences between pairs of means'; this enabled pairs of means to be compared by $t$ tests when significant effects were found in the analyses of variance. In this analysis the degrees of freedom for the $t$ statistic are those of the appropriate error term in the analysis of variance-namely, (No of subjects -1) $\times$ (No of doses -1$)$ or (No of subjects -1$) \times($ No of time points -1$)$.

\section{Results}

Table I shows the mean increases in weal thickness for each treatment, averaged over all subjects and all times, for the three different doses of bradykinin. The standard errors of the differences between pairs of means are also given. For each treatment $10 \mu \mathrm{g}$ bradykinin produced a significantly greater response than $3 \mu \mathrm{g}\left(t_{10}=7 \cdot 1,9 \cdot 5\right.$, and $9 \cdot 2$ for captopril, enalapril, and placebo, respectively; $p<0.001$ for all), but the effect of $3 \mu \mathrm{g}$ was not significantly different from that of $1 \mu \mathrm{g}$.

Table II shows the mean increases in weal thickness for each treatment, averaged over all subjects and doses, at each of the four times at which

TABLE I-Mean increase in skin weal thickness ( $\mathrm{mm}$ ) 20 minutes after intradermal injection of bradykinin by dose

\begin{tabular}{|c|c|c|c|c|}
\hline \multirow[b]{2}{*}{ Treatment } & \multicolumn{3}{|c|}{ Bradykinin dose $(\mu \mathrm{g})$} & \multirow[b]{2}{*}{$\mathrm{SE}^{\star}$} \\
\hline & 1 & 3 & 10 & \\
\hline $\begin{array}{l}\text { Placebo } \\
\text { Captopril } 25 \mathrm{mg} \\
\text { Enalapril } 10 \mathrm{mg}\end{array}$ & $\begin{array}{l}0.34 \\
0.37 \\
0.48\end{array}$ & $\begin{array}{l}0.47 \\
0.48 \\
0.64\end{array}$ & $\begin{array}{l}1 \cdot 13 t \\
1.02 t \\
1.48 \dagger\end{array}$ & $\begin{array}{l}0.07 \\
0.08 \\
0.09\end{array}$ \\
\hline
\end{tabular}

$\star S E$ of difference between pairs of means.

tp $<0.001$ Compared with $3 \mu \mathrm{g}$ dose.

TABLE II-Mean increase in skin weal thickness (mm) 20 minutes after intradermal injection of bradykinin related to time after treatment

\begin{tabular}{lccccc}
\hline & & \multicolumn{3}{c}{ Time after treatment (h) } & \\
\cline { 3 - 5 } Treatment & Before treatment & 2.5 & 5 & 7.5 & SE $^{\star}$ \\
\hline Placebo & 0.66 & 0.67 & 0.67 & 0.58 & 0.08 \\
Captopril 25 mg & 0.57 & 0.71 & 0.60 & 0.61 & 0.09 \\
Enalapril 10 mg & 0.61 & $1.12 \mathrm{t}$ & $1.06 t$ & 0.68 & 0.10 \\
\hline
\end{tabular}

*SE of difference between pairs of means.

tp $<0.001$ Compared with pretreatment mean. bradykinin was given. The standard errors are also shown. The mean responses to bradykinin were similar before and at all times after the administration of placebo. The administration of captopril caused now significant change in the response to bradykinin. A significant increase in the mean response was, however, observed two and a half hours $\left(t_{15}=4.9, \frac{\mathrm{D}}{\mathrm{D}}\right.$ $\mathrm{p}<0.001)$ and five hours $\left(t_{15}=4.4, \mathrm{p}<0.001\right)$ after the administration of enalapril. There was no significant change in blood pressure or heart rate with either drug.

All subjects experienced mild pain 20-30 seconds after the injection of $10 \overline{\bar{\nabla}}$ $\mu \mathrm{g}$ bradykinin and sometimes after the injection of the $3 \mu \mathrm{g}$ dose, but? neither angiotensin converting enzyme inhibitor seemed to increase thes intensity or duration of the pain.

During the study most subjects noticed a sensation of facial burning and. appeared flushed three or four minutes after the administration of brady $\Rightarrow$ kinin. In some instances the flushing was accompanied by conjunctival? suffusion, nasal stuffiness, and cough. When the trial had been completed ito was evident that the symptoms had occurred only after the subjects receivedo angiotensin converting enzyme inhibitors. No subject experienced the $\overline{\bar{c}}$. symptoms after placebo or before the administration of either inhibitor. Five subjects flushed when bradykinin was given two and a half hours after captopril but not subsequently; and four subjects flushed each time that bradykinin was given after enalapril.

\section{Discussic al}

This stl. '? showed that angiotensin converting enzyme inhibitorsin

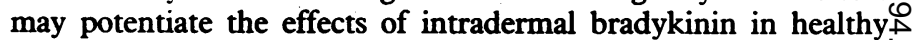
subjects. Enalapril produced an unequivocal increase in the wealo response to intradermal bradykinin, and after receiving the enzyme inhibitors subjects developed symptoms and signs (facial flushing, conjunctival suffusion, nasal stuffiness, cough) attributable to the $\overrightarrow{ }$ effects of systemic bradykinin. These effects presumably occurred as a result of diminished metabolism of bradykinin in the skin and its consequent absorption into the systemic circulation. The ${ }_{3}^{N}$ absence of any enhanced local effect of bradykinin after administration of captopril may be due to captopril's comparatively short half life and the low dose used in this study. The time course of the response to bradykinin after enalapril is compatible with enalapril's. duration of action. ${ }^{10}$

The finding that angiotensin converting enzyme inhibitors potentiate the effects of intradermal bradykinin partly explains the development of angio-oedema with these drugs. It may also partially explain the flushing and cough that have been associated with these $\underset{\Omega}{\mathbb{\Phi}}$ compounds in some patients. ${ }^{11}$ Detailed studies of such patients are $\Rightarrow$ needed to show whether they have abnormalities of bradykinin 3 production, sensitivity, or destruction that are exacerbated by the $\overrightarrow{ }$ inhibition of angiotensin converting enzyme (that is, kininase II).

\section{References}

1 Lawson DH, Chalmers D, Dombey S. Postmarketing surveillance of captopril for hypertension . Third world conference of clinical pharmacology and therapeutics. Stockholm: Gotab, 1986. 2 Committee on the Safety of Medicines. Adverse reactions to enalapril (Innovace). Current Problems 1986;17:1-2.

3 Wood SM, Mann RD, Rawlins MD. Angio-oedema and urticaria in association with angiotensin converting enzyme inhibitors. Br Med f 1987;294:91-2.

4 Spragg J, Talamo RC, Austen KF. Immunochemistry of bradykinin and immunologic activation $\mathrm{CJ}$ of the kinins. In: Erdos EG, ed. Bradykinin, kallidin and kallikrein. Berlin: Springer-Verlag, D 1970.

5 Yang HY, Erdos EG, Levin Y. Characterization of a dipeptide hydrolase (kininase II: angiotensin I converting enzyme). F Pharmacol Exp Ther 1971;177:291-300.

Kiowski $W$, van Brummelen $P$, Hulthen L, Amann FW, Buhler FR. Antihypertensive and rena effects of captopril in relation to renin activity and bradykinin-induced vasodilation. Clincu effects of captopril in relation to renin activity and bradykinin-induced vasodilation. Clinco
$P$ Pharmacol Ther 1982;31:677-90.

7 Atlas SA, Case DB, Zhung YY, Lavagh JH. Hormonal and metabolic effects of angiotensinconverting enzyme inhibitors. Am $\mathcal{J}$ Med 1984;77:13-7.

8 Cook JJ, Shuster S. Histamine weal formation and absorption in man. Br $\mathrm{J}$ Pharmacof 1980;69:579-85.

9 Baker RJ, Nelder JA. GLIM manual. Release 3. Oxford: Numerical Algorithms Group, 1978. $10 \mathrm{Kubo}$ SH, Cody RJ. Clinical pharmacokinetics of the angiotensin converting enzyme inhibitors. T Clin Pharmacokinet 1985; 10:377-91.

11 Semple PF, Herd GW. Cough and wheeze caused by inhibitors of angiotensin-converting enzyme. NEngl I Med 1986;314:61.

(Accepeed 5 March 1987) 